\title{
The 4th International Palaeoflood Workshop and trends in palaeoflood science
}

\author{
J.C. Woodward ${ }^{\mathrm{a}, *}$, S. Tooth ${ }^{\mathrm{b}}$, P.A. Brewer ${ }^{\mathrm{b}}$, M.G. Macklin ${ }^{\mathrm{b}}$ \\ a Geography, School of Environment and Development, The University of Manchester, Manchester, M13 9PL, UK \\ b Institute of Geography and Earth Sciences, Aberystwyth University, Aberystwyth, SY23 3DB, UK
}

\section{A R T I C L E I N F O}

\section{Article history:}

Accepted 6 November 2009

Available online 15 November 2009

\section{Keywords:}

Palaeoflood science

Global change

Flooding

Geochronology

Flood geomorphology

Hydraulic modelling

\begin{abstract}
A B S T R A C T
Palaeoflood research has developed rapidly since the 1970s as the value of assembling long flood histories has become more widely appreciated across the Earth and environmental sciences, and in river basin management and related policy formulation. Palaeoflood science links several disciplines and involves a wide range of field-based, theoretical, and modelling approaches. Increasingly, researchers are using palaeoflood data to explore linkages between various components of global change and the past dynamics of river systems. Pleistocene and Holocene flood records are now providing essential context for the short gauged records that are commonly used for flood hazard assessment and river basin management. Recent advances in palaeoflood science were presented at the 4th International Palaeoflood Workshop in Crete in June 2007. This paper reviews the background to this meeting, sets out the structure and key themes of this special issue, and outlines potential future research directions.
\end{abstract}

(c) 2009 Elsevier B.V. All rights reserved.

\section{Introduction}

This special issue contains twelve papers that were presented at the 4th International Palaeoflood Workshop (IPW) in Chania, Crete, in June 2007. The aims of the workshop were to bring together researchers and practitioners interested in new methods, empirical datasets, conceptual models and theoretical developments in palaeoflood hydrology, and to provide an opportunity to take stock of recent developments in the field and identify avenues for future research. The workshop was attended by over 40 delegates from 11 countries (Fig. 1), with most delegates coming from Europe, North America and Israel but also from South Korea, Japan and New Zealand. The Crete workshop continued the series of meetings dedicated to palaeoflood hydrology (Table 1) that over time have become known as the International Palaeoflood Workshops, and was the first such meeting to be held outside North America.

Palaeoflood hydrology emerged as a distinct field of scientific study in the 1970s and was first formally named by Kochel and Baker (1982). The first IPW, organised by Vic Baker (Fig. 2), was held in Flagstaff, Arizona, in May 1992 (Table 1), and so at the Crete workshop it was fitting that Vic should deliver the opening address entitled Palaeoflood Hydrology: Past, Present, and Future. This address provided a primer for his recent review of the origin and status of palaeoflood hydrology, including the background to the IPW series (Baker, 2008). From this review and earlier overviews (e.g. Costa, 1987; Baker et al. 1988; House et al., 2002; Saint-Laurent, 2004), the papers included in

\footnotetext{
* Corresponding author.

E-mail address: jamie.woodward@manchester.ac.uk (J.C. Woodward).
}

this special issue, and other contributions to the Crete workshop, it is clear that the international palaeoflood community has grown rapidly over the last few decades. Active research groups are now well established in many parts of the world and sessions on palaeoflooding and the links to past hydroclimates are regularly held at a range of international scientific meetings such as the annual conference of the European Geophysical Union. Research in this field has flourished as the theoretical and practical value of establishing long flood histories has become more widely appreciated across the Earth and environmental sciences and by those involved in river basin management and policy formulation.

Traditional approaches to flood hazard estimation have involved the use of monitored flood records to estimate flood frequency and magnitude relationships, but a key contribution of palaeoflood hydrology has been a clear demonstration of the need to use the palaeoflood record to provide the longer-term context for these typically very short records (Baker et al., 1988; Benito and Thorndycraft, 2005; Baker, 2008; Costa and Jarrett, 2008). The value of this approach is especially significant in the context of the current focus on global climate change. While flooding does play a vital and beneficial role in hydrological and biogeochemical cycles (e.g. in aquifer recharge or in sediment and nutrient transfer), floods are also one of the most significant and widespread natural hazards, accounting for some of the greatest losses of life annually and the greatest economic losses (Parker, 2000; Schanze et al., 2006; Llasat, 2009). Globally, huge sums are invested annually in flood defence and flood risk management schemes (Schanze et al., 2006), particularly as urban and industrial developments continue to encroach on flood-prone terrain in riverine or coastal locations. There is widespread concern for the potential impacts that climate change could have on the global hydrological cycle (Parry et al., 


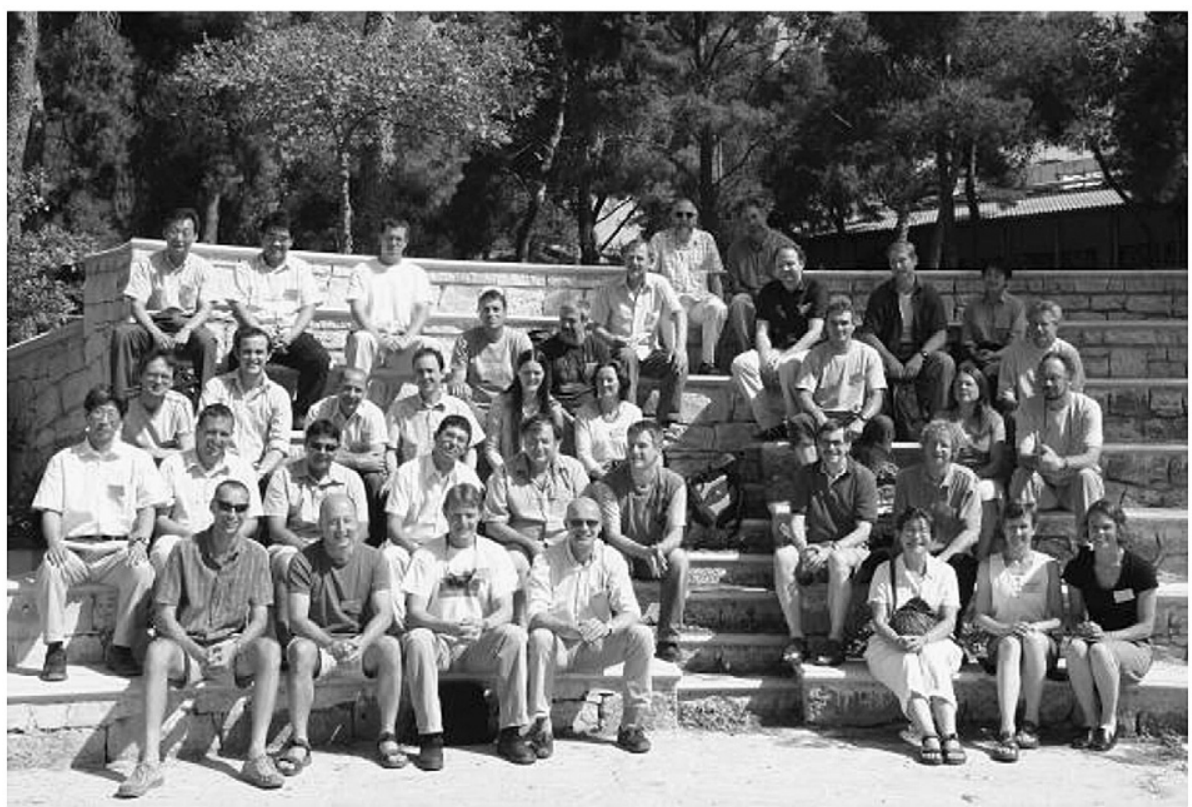

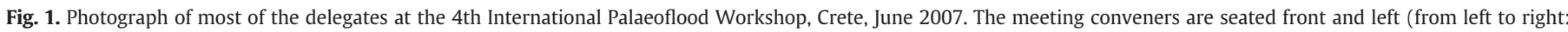
Brewer, Macklin, Tooth and Woodward). The paper sessions were held at the Mediterranean Agronomic Institute of Chania (MAICh).

2001), especially on hydrological extremes such as floods and droughts, yet these impacts are one of the major areas of uncertainty in the latest IPCC (2007) report. In the very week that the Crete workshop took place, the National Observatory of Athens recorded its highest ever temperature $\left(44.8^{\circ} \mathrm{C}\right)$ on 26 th June, which was part of a series of intense heatwaves in summer 2007 across the eastern Mediterranean (Founda and Giannakopoulos, 2009). At the same time, the UK was subjected to the most extensive and severe summer floods on record (Marsh and Hannaford, 2007; Marsh, 2008). Against this backdrop of concern for present and future change, many researchers are using palaeoflood data to explore linkages between various components of global change and the past dynamics of river systems (e.g. Macklin and Lewin, 2008; Baker, 2008). In addition, studies of flood-generating processes and the characteristics of extreme floods are providing insight into the causes, processes and limits of variability in past flooding, with implications for our understanding of the impacts of Pleistocene and Holocene environmental change on landscape development and societal response. This is helping to contextualise present flood events and provide a more robust framework for anticipating and mitigating future events.

At the Crete workshop, new research findings focused on these themes and many related issues were presented from river catchments across five continents. The increasingly multi- and inter-disciplinary character of palaeoflood science was particularly evident. The workshop involved delegates with backgrounds in Quaternary geology, fluvial geomorphology, catchment hydrology, palaeoclimatology, environmental modelling and remote sensing, geoarchaeology, hydraulic engineering and flood management. The six-day meeting involved two days of technical sessions, a one-day mid-workshop field excursion to the Samaria Gorge in southwestern Crete, and a three-day post-workshop

Table 1

International Palaeoflood Workshops 1992-2007 (modified from Baker, 2008).

\begin{tabular}{|c|c|c|}
\hline Venue & Dates & Convened by: \\
\hline 1. Flagstaff, Arizona, USA & May 26-30, 1992 & V.R. Baker \\
\hline 2. Prescott, Arizona, USA & Sept 26-Oct 1, 1999 & P.K. House \\
\hline 3. Hood River, Oregon, USA & August 1-7, 2003 & L. Ely, J.E. O'Connor and P.K. House \\
\hline 4. Chania, Crete, Greece & June $24-30,2007$ & $\begin{array}{l}\text { P.A. Brewer, M.G. Macklin, } \\
\text { S. Tooth and J.C. Woodward }\end{array}$ \\
\hline
\end{tabular}

field excursion that focused on the spectacular mountain, gorge and coastal landscapes of central and eastern Crete. Abstracts of all the oral papers and posters presented at the meeting can be found in Tooth and Woodward (2007), and conference and field trip reports were published in Geophemera (2007, Volume 101, 29-30) http://www.geomorphology. org.uk/pages/geophemera/past/.

\section{Structure and key themes of this special issue}

This is the first time that papers from an IPW have been published together in a single volume. In view of the central role of flooding in past, present, and future trajectories of change in the Earth system and on some other planetary bodies, and the increasingly multi- and interdisciplinary nature of palaeoflood science, it is fitting that these papers should appear in Global and Planetary Change. The papers have been organised into three parts that address palaeoflood phenomena from very large spatial and long temporal scales down to smaller spatial and shorter temporal scales: (1) Megafloods on Earth, Mars and Titan; (2) Late Pleistocene and Holocene flood histories: geomorphological and sedimentological records; and (3) Historical and monitored records of high magnitude floods.

In terms of the methods employed, the wide range of temporal scales addressed, and the geographical scope, the papers published here are broadly representative of those presented at the Crete meeting. The papers examine extreme floods across a range of geomorphological settings, including megaflows on other planetary bodies (Mars, Titan) and in southern Siberia (these include some of the largest floods so far identified in the Earth's geological record), as well as destructive floods in small desert wadis in Israel and Egypt. The papers highlight the range of mechanisms that can generate large and extreme floods, including ice dam breaks, caldera lake breaches, high-intensity rainfall, and rapid snowmelt. The diverse sources of evidence and the different approaches used in palaeoflood reconstruction are also evident, including satellite remote sensing, hydraulic modelling, archival studies and field-based investigations. The latter include studies of coarse-grained sediments in small, highenergy, steepland rivers (commonly within bedrock-controlled reaches) as well as investigations of fine-grained sediments associated with larger, lower-energy, lowland alluvial rivers. Several papers integrate data from multiple sources and use a variety of approaches 


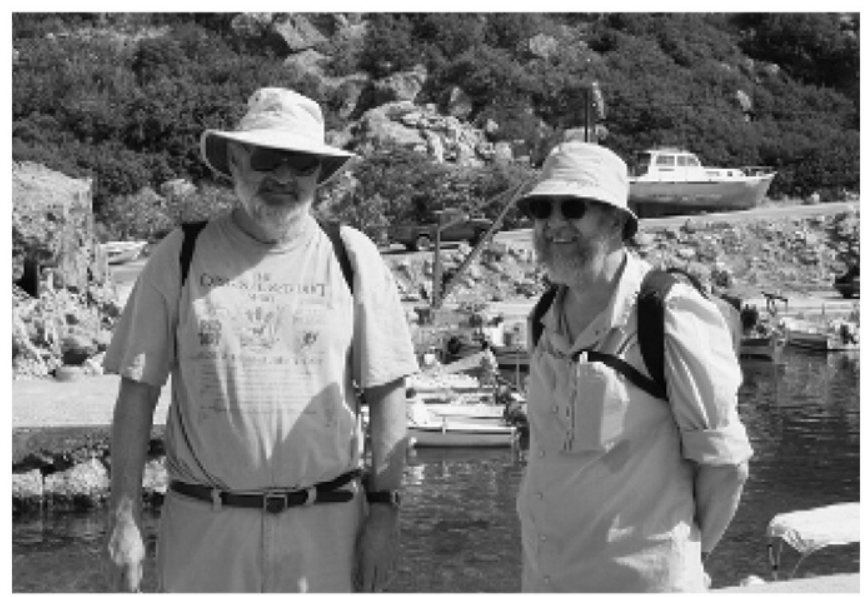

Fig. 2. Vic Baker and John Lewin on the mid-workshop field excursion to the Samaria Gorge, southwestern Crete.

to produce long records of flood frequency and magnitude that can be evaluated against high-resolution records of climate change.

\section{Future research directions in palaeoflood studies}

The final session at the Crete workshop was an open discussion entitled Advances and Futures in Palaeoflood Hydrology that was chaired by John Lewin (Fig. 2). This generated a lively, wide-ranging and productive assessment of some of the key advances in palaeoflood science presented at the workshop, along with identification of gaps in understanding and suggestions for future research directions. The following extract from Baker (2008, p. 9) provides useful context for this discussion:

"Just as flood hydrology in the past two decades has experienced a revolutionary development of quantitative computer models, so has a contemporaneous revolution in the methodology for accomplishing paleoflood hydrology. Whereas the computer modeling revolution extends mathematical idealizations of nature to phenomena that defy realistic testing, the paleoflood revolution, however, involves the accurate recovery of magnitudes and ages for the largest floods to have actually occurred during the past millennia."

As this quotation implies, and as was highlighted in the open discussion, the 'palaeoflood revolution' has been achieved in large part by improving the dating frameworks for the palaeoflood record and the Quaternary fluvial archive more generally, as demonstrated for river systems in the Mediterranean basin for example (see Macklin and Woodward, 2009). Over the last decade or so, the wider application of optically stimulated luminescence dating in arid and semi-arid fluvial environments in particular has been a key advance (Tooth, 2007), enabling more robust dating frameworks to be assembled for Late Pleistocene and Holocene flood records in areas such as the desert Nile (Woodward et al., 2001) where the opportunities for widespread application of other dating techniques such as radiocarbon $\left({ }^{14} \mathrm{C}\right)$ tend to be limited. At the same time, the increasing number of radiocarbon-dated fluvial records for humid, temperate - as well as Mediterranean - river systems has enabled ${ }^{14} \mathrm{C}$ databases to be compiled, allowing long-term trends in flooding and fluvial sedimentation to be interrogated in new ways (e.g. Macklin and Lewin, 2003; Thorndycraft and Benito, 2006). Greater use of quantitative sediment sourcing of slackwater sediments also offers considerable potential to improve understanding of flood generation mechanisms and how these may change during periods of rapid environmental change (Woodward et al., 2008). It can be argued, however, that there has been a research bias towards high-energy, fast-moving floods in high-gradient river systems, with rather less attention directed towards high-magnitude but lower-energy, slower-moving floods such as those that characterise large, lowgradient ephemeral river systems (e.g. Knighton and Nanson, 2001) or tropical and subtropical wetland systems (e.g. Gumbricht et al., 2004). In part, this reflects a natural tendency to focus research on the impacts of the spectacular, high-energy destructive flood events, but also highlights the practical difficulties of studying lower-energy floods of great spatial extent and duration. New methods of detecting, mapping and monitoring these latter types of flood event autonomously from space (e.g. Brakenridge et al., 2007) may help to redress this research imbalance, however, particularly by improving our ability to characterise such floods in near real time by processing the data onboard the spacecraft and by reacting to detected events so that additional scenes are acquired (Ip et al., 2006). Against this backdrop, there also appears to be scope to link what might be termed 'upland' and 'lowland' palaeoflood research; for instance, by extending recent innovations that use high-resolution sedimentological and geochemical scanning of Holocene floodplain sediment cores to identify signatures of discrete flood events in upland and lowland fluvial records (Jones, 2007). In some settings, it may then be possible to move towards long reconstructions of riverine flood records on decadal or annual timescales, rivalling the length and resolution of some palaeorecords reconstructed for flood-prone coastal locations that are subject to tropical cyclone activity (e.g. Nott, 2007; Nott et al., 2007).

It was clear from both the technical and discussion sessions at the Crete workshop, and as featured in some of the papers in this special issue, that computationally-driven hydraulic modelling approaches are now being integrated much more effectively with geomorphological, sedimentological and archival data on the magnitude and frequency of past floods. Energy-based inverse hydraulic modelling is now routinely used in many studies (Baker, 2008; Costa and Jarrett, 2008). The ability to model extreme flood events (not only on Earth but also on other planetary bodies) that are beyond the realm of direct monitoring or observation, and that are not related to weather conditions (e.g. catastrophic ice dam breaks), has advanced considerably, and this is providing valuable insights into the dynamics of these extreme events and the mechanisms responsible for the formation of giant subaqueous bedforms and other fluvial landforms. As our understanding of the largest floods advances, the challenge will be to scale down the modelling of these rare, extreme events and improve the modelling of more frequent, smaller floods that impact more commonly on burgeoning human populations. A related hurdle still to be overcome is the mismatch in scale between the outputs from General Circulation Climate Models that focus on large-scale climate dynamics but do not as effectively simulate flood-producing weather patterns.

Despite these challenges, there are many examples where research has been conducted across traditionally disparate disciplinary boundaries to integrate different kinds of data and improve understanding of both modern and past flood phenomena. A remaining - and arguably bigger - challenge for the future, however, will be to interface more effectively between science and policy. While palaeoflood researchers have had some success in this respect (particularly in Australia and North America, see Baker, 2008), there is still considerable scope for raising awareness of the value of palaeoflood science in river basin management (Costa and Jarrett, 2008).

\section{Acknowledgements}

We thank all the reviewers who helped in the preparation of this special issue: Gerardo Benito, Nati Bergman, James Brasington, Devon Burr, Paul Carling, Maria del Carmen Llasat, Martin Evans, Ian Foster, Jeanne Godaire, Gordon Grant, Noam Greenbaum, Avi Gupta, Alan Kehew, Jim Knox, Juergen Herget, John Lewin, Neil Macdonald, Vern 
Manville, Andrew Nicholas, Richard Pope, David Pyle, Barbara Rumsby, Tim van der Schriek and Varyl Thorndycraft. We would also like to thank Aberystwyth University, The University of Manchester, and The British Society for Geomorphology for providing financial support for the 4th IPW, and all the staff at The Mediterranean Agronomic Institute of Chania (MAICh) and Ibis el Greco who helped to make this an extremely enjoyable and successful workshop. Thanks are also extended to Nick Scarle in the Cartographic Unit (School of Environment and Development) at The University of Manchester for redrawing many of the figures in this special issue.

\section{References}

Baker, V.R., 2008. Paleoflood hydrology: origin, progress, prospects. Geomorphology 101, 1-13.

Baker, V.R., Kochel, R.C., Patton, P.C. (Eds.), 1988. Flood geomorphology. John Wiley and Sons, Chichester.

Benito, G., Thorndycraft, V.R., 2005. Palaeoflood hydrology and its role in applied hydrological sciences. Journal of Hydrology 313, 3-15.

Brakenridge, G.R., Nghiem, S.V., Anderson, E., Mic, R., 2007. Orbital microwave measurement of river discharge and ice status. Water Resources Research 43 , W04405. doi:10.1029/2006WR005238.

Costa, J.E., 1987. A history of paleoflood hydrology in the United States, 1800-1970. History of Hydrology. In: Landa, E.R., Ince, S. (Eds.), History of Geophysics, vol. 3. American Geophysical Union, pp. 49-53.

Costa, J.E., Jarrett, R.D., 2008. An evaluation of selected extraordinary floods in the United States reported by the U.S. Geological Survey and implications for future advancement of flood science. United States Geological Survey Scientific Investigations Report 2008-5164. 232 pp.

Founda, D., Giannakopoulos, C., 2009. The exceptionally hot summer of 2007 in Athens, Greece - a typical summer in the future climate? Global and Planetary Change 67, 227-236.

Gumbricht, T., Wolski, P., Frost, P., McCarthy, T.S., 2004. Forecasting the spatial extent of the annual flood in the Okavango delta, Botswana. Journal of Hydrology 290 $178-191$.

House, P.K., Webb, R.H., Baker, V.R., Levish, D.R. (Eds.), 2002. Ancient floods, modern hazards - principles and applications of paleoflood hydrology. American Geophysical Union Water Science and Application Series, 5. 385 pp.

Intergovernmental Panel on Climate Change (IPCC), 2007. Climate Change 2007: Synthesis Report. Summary for Policymakers. Contribution of Working Groups I, II and III to the Fourth Assessment. IPCC, Geneva.

Ip, F., Dohm, J.M., Baker, V.R., Doggett, T., Davies, A.G., Castaño, R., Chien, S., Cichy, B., Greeley, R., Sherwood, R., Tran, D., Rabideau, G., 2006. Flood detection and monitoring with the Autonomous Sciencecraft Experiment onboard EO-1. Remote Sensing of the Environment 101, 463-481.
Jones, A.F., 2007. Reconstructing Historical and Holocene Flooding in Welsh River Catchments. Unpublished PhD Thesis, University of Wales, Aberystwyth.

Knighton, A.D., Nanson, G.C., 2001. An event-based approach to the hydrology of arid zone rivers in the Channel Country of Australia. Journal of Hydrology 254, 102-123.

Kochel, R.C., Baker, V.R., 1982. Paleoflood hydrology. Science 215, 353-361.

Llasat, M.C., 2009. Storms and floods. In: Woodward, J.C. (Ed.), The Physical Geography of the Mediterranean. Oxford University Press, Oxford, pp. 513-540.

Macklin, M.G., Lewin, J., 2003. River sediments, great floods and centennial-scale Holocene climate change. Journal of Quaternary Science 18, 101-105.

Macklin, M.G., Lewin, J., 2008. Alluvial responses to the changing Earth system. Earth Surface Processes and Landforms 33, 1374-1395.

Macklin, M.G., Woodward, J.C., 2009. River systems and environmental change. In: Woodward, J.C. (Ed.), The Physical Geography of the Mediterranean. Oxford University Press, Oxford, pp. 319-352.

Marsh, T.J., 2008. A hydrological overview of the summer 2007 floods in England and Wales. Weather 63, 274-279.

Marsh, T.J., Hannaford, J., 2007. The summer 2007 floods in England and Wales - a hydrological appraisal. Centre for Ecology and Hydrology. 32 pp. www.ceh.ac.uk.

Nott, J., 2007. The importance of Quaternary records in reducing risk from tropical cyclones. Palaeogeography, Palaeoclimatology, Palaeoecology 251, 137-149.

Nott, J., Haig, J.E., Neil, H., Gillieson, D.S., 2007. Greater frequency variability of landfalling tropical cyclones at centennial compared to seasonal and decadal scales. Earth and Planetary Science Letters 255, 367-372.

Parker, D.J. (Ed.), 2000. Floods (2 Volumes). Routledge, London.

Parry, M., Arnell, N., McMichael, A., Nicholls, R., Martens, P., Kovats, S., Livermore, M. Rosenzweig, C., Iglesias, A., Fischer, G., 2001. Millions at risk: defining critical climate change threats and targets. Global Environmental Change 11, 181-183.

Saint-Laurent, D., 2004. Palaeoflood hydrology: an emerging science. Progress in Physical Geography 28, 531-543.

Schanze, J., Zeman, E., Marsalek, J. (Eds.), 2006. Flood Risk Management: Hazards, Vulnerability and Mitigation Measures. NATO Science Series, IV Earth and Environmental Sciences, vol. 67. Springer, The Netherlands.

Thorndycraft, V.R., Benito, G., 2006. The Holocene fluvial chronology of Spain: evidence from a newly compiled radiocarbon database. Quaternary Science Reviews 25, 223-234.

Tooth, S., 2007. Arid geomorphology: investigating past, present and future changes Progress in Physical Geography 31, 319-335.

Tooth, S. and Woodward, J.C. (Eds.), 2007. Programme and Abstracts, 4th Internationa Palaeoflood Workshop, Crete, 24th-30th June, 2007. Available from the authors and at: http://www.sed.manchester.ac.uk/geography/staff/woodward_jamie.htm.

Woodward, J.C., Macklin, M.G., Welsby, D.A., 2001. The Holocene fluvial sedimentary record and alluvial geoarchaeology in the Nile Valley of Northern Sudan. In: Maddy, D.R. Macklin, M.G., Woodward, J.C. (Eds.), River Basin Sediment Systems: Archives of Environmental Change. A.A. Balkema, Rotterdam, pp. 327-356.

Woodward, J.C., Hamlin, R.H.B., Macklin, M.G., Hughes, P.D., Lewin, J., 2008. Glacial activity and catchment dynamics in northwest Greece: long-term river behaviou and the slackwater sediment record for the last glacial to interglacial transition. Geomorphology 101, 44-67. 